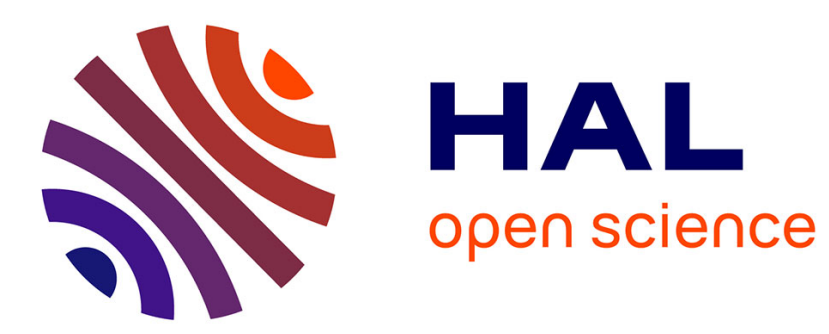

\title{
Thermal oxidation of poly(dicyclopentadiene) - Effect of phenolic and hindered amine stabilizers
}

Jing Huang, Pierre Yves Le Gac, Emmanuel Richaud

\section{To cite this version:}

Jing Huang, Pierre Yves Le Gac, Emmanuel Richaud. Thermal oxidation of poly(dicyclopentadiene) - Effect of phenolic and hindered amine stabilizers. Polymer Degradation and Stability, 2021, 183, pp.109267. 10.1016/j.polymdegradstab.2020.109267 . hal-03158968

\section{HAL Id: hal-03158968 https://hal.science/hal-03158968}

Submitted on 4 Mar 2021

HAL is a multi-disciplinary open access archive for the deposit and dissemination of scientific research documents, whether they are published or not. The documents may come from teaching and research institutions in France or abroad, or from public or private research centers.
L'archive ouverte pluridisciplinaire HAL, est destinée au dépôt et à la diffusion de documents scientifiques de niveau recherche, publiés ou non, émanant des établissements d'enseignement et de recherche français ou étrangers, des laboratoires publics ou privés. 


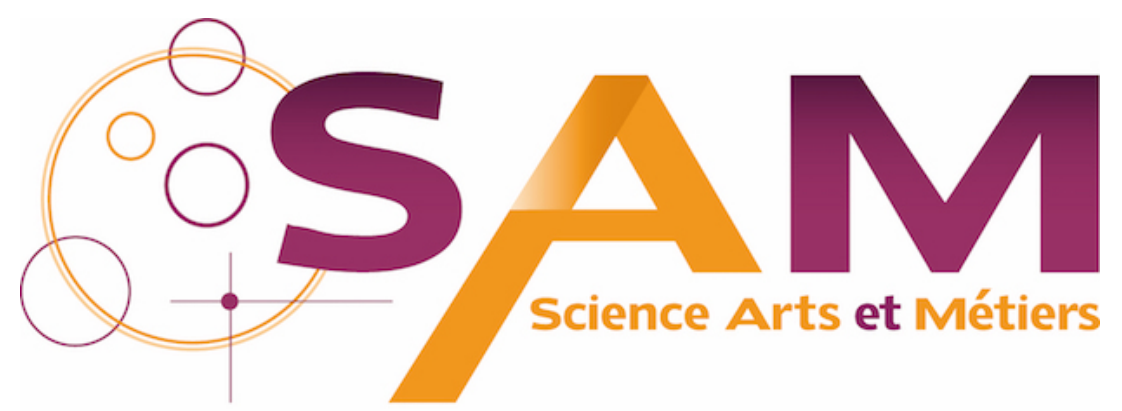

Archive Ouverte - Open Repository

\section{Science Arts \& Métiers (SAM)}

is an open access repository that collects the work of Arts et Métiers Institute of Technology researchers and makes it freely available over the web where possible.

This is an author-deposited version published in: https://sam.ensam.eu Handle ID: .http://hdl.handle.net/null

\section{To cite this version :}

Jing HUANG, Pierre YVES LE GAC, Emmanuel RICHAUD - Thermal oxidation of poly(dicyclopentadiene) - Effect of phenolic and hindered amine stabilizers - Polymer Degradation and Stability - Vol. 183, p.109267 - 2021 


\title{
Thermal oxidation of poly(dicyclopentadiene) - Effect of phenolic and hindered amine stabilizers
}

\author{
Jing Huang ${ }^{\mathrm{a}}$, Pierre Yves Le Gac ${ }^{\mathrm{b}}$, Emmanuel Richaud ${ }^{\mathrm{a}, *}$ \\ a Laboratoire PIMM, Arts et Metiers Institute of Technology, CNRS, Cnam, HESAM Université, 151 boulevard de l'Hôpital, 75013, Paris, France \\ ${ }^{\mathrm{b}}$ IFREMER, Service Matériaux et Structures, Centre de Brest BP70, 29280, Plouzané, France
}

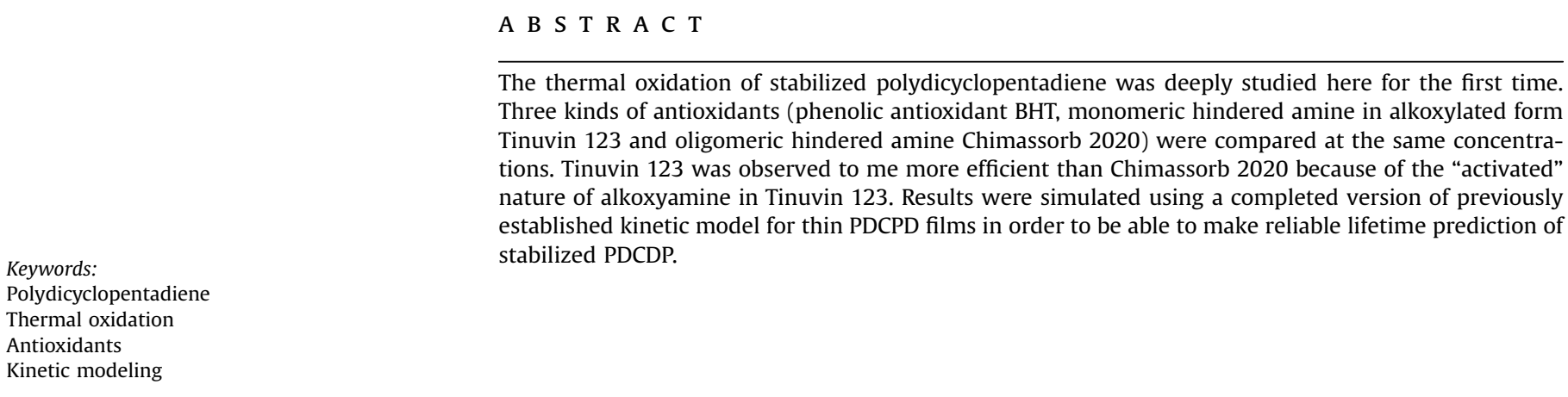

\section{Introduction}

The long term use of hydrocarbon polymers such as polyolefins and rubbers is made possible if they are efficiently protected against degradation (here oxidation) using stabilizers such as phenolic antioxidants or hindered amine stabilizers. The mechanisms of action of these latter are well documented [1,2] together with the matter that physical phenomena (diffusion, solubility, loss by evaporation ...) have a first order influence on their efficiency $[3,4]$. After decades of intensive researches, many solutions are available depending of the polymer nature, use temperature and geometry [5]. The case of PDCPD is however original and not addressed to our knowledge in existing scientific literature. It is particularly challenging for two reasons:

- Additive free PDCPD undergoes fast oxidation because of the presence of polymerization catalysts favors the decomposition of hydroperoxides [6], and low segmental mobility slowing down the termination process $[7,8]$.

- PDCPD is usually manufactured by a reactive process where monomer + precatalyst (part A) and monomer + activator (part B) are mixed through a mixing head. The reaction between

\footnotetext{
* Corresponding author.

E-mail address: emmanuel.richaud@ensam.eu (E. Richaud).
}

activator and procatalysts generates catalyst of Ring Opening Metathesis Polymerization and makes possible the network synthesis. Antioxidants are directly added to part A or part B and must not interact with the ROMP mechanism (a nice example of antioxidant preventing crosslinking is the case of irradiation crosslinked UHMWPE where a detrimental effect of vitamin $\mathrm{E}$ on the crosslinking was observed since phenol group react with gamma induced radicals generated by radiolysis [9]).

The aim of the present work is hence to investigate possible pathways of PDCPD stabilization by screening stabilizers with different action mechanisms (phenolic antioxidants one (reacting by a sacrificial process) vs hindered amine stabilizers (reacting by a regenerative mechanism), molar mass (« monomeric » vs « oligomeric » stabilizers triggering their physical performances) and initial « activated» state (secondary vs alkoxyamine for HAS). The thermal ageing of samples with various stabilizer concentrations will be studied at 3 different temperatures to investigate the effect of this latter on stabilizers efficiency. Based on experimental results, we will be able to choose stabilizers offering better balance between kinetic of ROMP polymerization and long term stability. Then, these results will be used to set up, for the first time, a kinetic model where stabilization rate constants will be either chosen for literature or determined from the simulation of our experimental results. This completed model will help to predict degradation kinetics in other conditions using extrapolated values of rate 
constants estimated in this work.

\section{Materials and methods}

\subsection{Materials}

The samples under investigation were supplied as stabilized bulk materials prepared by reaction injection molding process at about $40^{\circ} \mathrm{C}$ from reactive mixture of dicyclopentadiene, ruthenium catalyst [6] and either butylated hydroxytoluene (BHT), or Tinuvin 123 or Chimassorb 2020 (Fig. 1). 6-15 $\mu \mathrm{m}$ thickness films were obtained from the bulk material using a microtome (RM 2255 Leica) and stored in fridge $\left(-20^{\circ} \mathrm{C}\right)$ for at most 7 days before ageing. The oxidation of additive free PDCPD samples with the same thickness was shown to be not limited by oxygen diffusion [8]. The thickness of oxidized layer of stabilized polymers was also shown to be higher for stabilized polymers than unstabilized ones [10]. We will thus assume that the oxidation of samples under investigation in this paper is not subject to control by oxygen diffusion.

Antioxidants were studied at the same 5 concentrations in active groups which was assessed from the overall mass fraction $\left(\mathrm{x}_{\mathrm{AH}}\right)$ by:

$[A H]=\frac{f_{A H} \times d_{P D C P D} \times x_{A H}}{M_{A H}}$

where:

- $\mathrm{M}_{\mathrm{AH}}\left(\mathrm{mol} \mathrm{g}^{-1}\right)$ is the molar mass of antioxidants equal to $220 \mathrm{~g} \mathrm{~mol}^{-1}$ for BHT, $737 \mathrm{~g} \mathrm{~mol}^{-1}$ for Tinuvin 123. It is reported to range between 2600 and $3400 \mathrm{~g} \mathrm{~mol}^{-1}$ for Chimassorb 2020

[11] which is an oligomer resulting from condensation reactions.

- $\mathrm{f}_{\mathrm{AH}}$ is the number of functionality equal to 1 for BHT, 2 for Tinuvin 123. For Chimassorb 2020, the average number of piperidine group per molecule would range from 8.75 to 12.2.

$-\mathrm{d}_{\text {DCPD }}$ is the density of PDCPD $\left(1 \mathrm{~g} \mathrm{~cm}^{3}\right)$.

The calculations of double bonds concentrations (needed for simulation part) were done using Beer-Lambert law from the peak of double bonds absorbance at $3050 \mathrm{~cm}^{-1}, 973 \mathrm{~cm}^{-1}$ and $733 \mathrm{~cm}^{-1}$ by FTIR [12]. The results are presented in Table 1 . Interestingly, the double bonds concentrations of stabilized PDCPD are slightly lower than the one of additive-free PDCPD [12].

\subsection{Ageing}

Samples were exposed at various temperatures (50, 90 and $120^{\circ} \mathrm{C}$ ) in air-ventilated ovens supplied by System Climatic Service under atmospheric air.

\subsection{FTIR}

The FTIR spectra were collected on a Frontier spectrometer (PerkinElmer) as the average of 4 scans performed over a spectral range from 400 to $4000 \mathrm{~cm}^{-1}$ with a resolution of $4 \mathrm{~cm}^{-1}$. Spectra were then analyzed with Spectrum ${ }^{\mathrm{TM}}$ software. The concentrations of carbonyls generated by oxidation were calculated using the BeerLambert equation with a molar absorptivity of $300 \mathrm{~mol} \mathrm{l}^{-1} \mathrm{~cm}^{-1}$ at $1710 \mathrm{~cm}^{-1}$ [7]. The methods for determining double bonds concentration was previously detailed in [13].

\section{Results}

\subsection{Compatibility study}

Since antioxidants must be compatible with the metathesis catalyst used to polymerize DCPD, we first decided to perform compatibility tests between polymerization catalysts and investigated stabilizers. For that purpose, the polymerization kinetics were followed (see Fig. 2). The smoke time (i.e. the onset time of the temperature vs time curves) for reactive mixtures containing stabilizers are lower than for unstabilized one, meanwhile the maximal temperature (linked to the polymerization yield) remains the same. In other words, it seems there is no detrimental interaction between catalysts and chosen stabilizers.

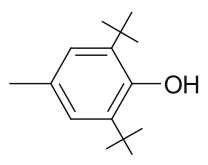

(a)

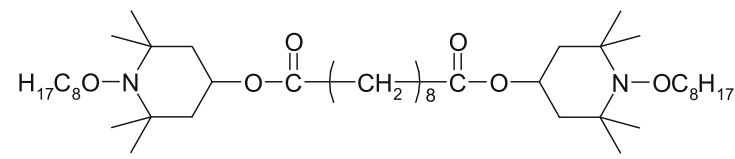

(b)

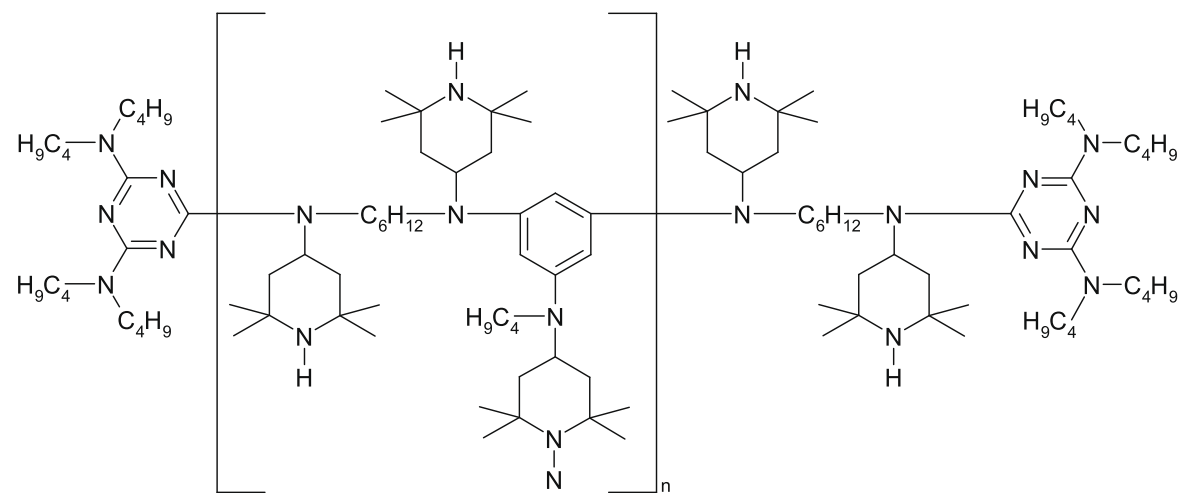

Fig. 1. Structure of BHT (a), Tinuvin 123 (b) and Chimassorb 2020 (c). 
Table 1

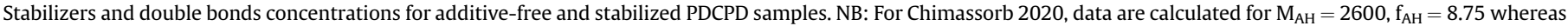
values in parentheses correspond to $\mathrm{M}_{\mathrm{AH}}=3400, \mathrm{f}_{\mathrm{AH}}=12.2$.

\begin{tabular}{|c|c|c|c|c|}
\hline Antioxidants & CAS & Mass fraction (\%) & {$[\mathrm{AH}]\left(\mathrm{mol} \mathrm{l}^{-1}\right)$} & {$\left[>\mathrm{C}=\mathrm{C}<\mathrm{]}\left(\mathrm{mol} \mathrm{l}^{-1}\right)\right.$} \\
\hline none & - & - & - & $12-13$ \\
\hline \multirow[t]{5}{*}{ BHT } & $128-37-0$ & 0.05 & $2.2710^{-3}$ & $8-9$ \\
\hline & & 0.1 & $4.5510^{-3}$ & $8-9$ \\
\hline & & 0.2 & $9.0910^{-3}$ & $8-9$ \\
\hline & & 0.5 & $2.2710^{-2}$ & $8-9$ \\
\hline & & 1 & $4.5510^{-2}$ & $8-9$ \\
\hline \multirow[t]{5}{*}{ Tinuvin 123} & $129757-67-1$ & 0.08 & $2.2710^{-3}$ & $9-10$ \\
\hline & & 0.17 & $4.5510^{-3}$ & $9-10$ \\
\hline & & 0.34 & $9.0910^{-3}$ & $9-10$ \\
\hline & & 0.84 & $2.2710^{-2}$ & $9-10$ \\
\hline & & 1.68 & $4.5510^{-2}$ & $9-10$ \\
\hline \multirow[t]{5}{*}{ Chimassorb 2020} & $192268-64-7$ & $0.068(0.063)$ & $2.2710^{-3}$ & $8-9$ \\
\hline & & $0.135(0.127)$ & $4.5510^{-3}$ & $8-9$ \\
\hline & & $0.27(0.253)$ & $9.0910^{-3}$ & $8-9$ \\
\hline & & $0.675(0.633)$ & $2.2710^{-2}$ & $8-9$ \\
\hline & & $1.351(1.267)$ & $4.5510^{-2}$ & $8-9$ \\
\hline
\end{tabular}

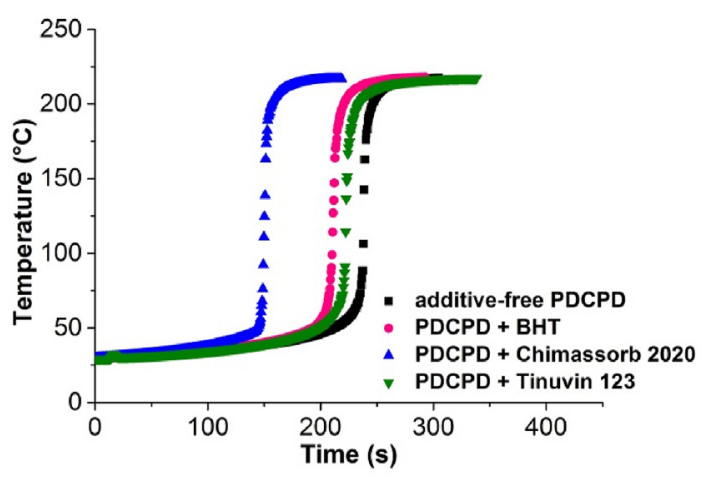

Fig. 2. Thermographs for ROMP of DCPD catalyzed by ruthenium metathesis catalyst with and without antioxidants.

\subsection{Initial characterization}

Samples were characterized by FTIR spectroscopy (Fig. 3) after processing, leading to the following observations:

- Tinuvin 123 is characterized by the absorption due to ester groups at about $1735 \mathrm{~cm}^{-1}$.

- Chimassorb 2020 is characterized by the absorption due to the triazine groups at about $1530 \mathrm{~cm}^{-1}$ (Fig. 3a).

- All absorbances are shown to linearly increase with stabilizer. The absence of concavity would indicate the absence of significant stabilizer loss during processing. The possible molar absorptivities would be around $5751 \mathrm{~mol}^{-1} \mathrm{~cm}^{-1}$ for ester groups in Tinuvin 123 (in line with the case of other stabilizers with aliphatic esters hold by flexible chains [13]) and $10901 \mathrm{~mol}^{-1} \mathrm{~cm}^{-1}$ for triazine groups (Fig. 3b).

- A small signal is detected in the $\mathrm{O}-\mathrm{H}$ et $\mathrm{N}-\mathrm{H}$ stretching region (see Appendix 1) but its amplitude is too low to permit a reliable method to monitor the residual stabilizer concentration.

- Interestingly for HAS and BHT stabilizers, a small signal is detected at $1720 \mathrm{~cm}^{-1}$ indicating a small pre-oxidation of samples irrespectively of their stabilizers package. This can be explained from their stabilization mechanism (recalled later) where hydroperoxides are generated from reactions between radicals and stabilizers and would almost instantaneously decompose in processing conditions.

\subsection{Ageing results}

Thermal oxidation of PDCPD with 5 different concentrations of each stabilizer was investigated at 50,90 and $120^{\circ} \mathrm{C}$ under in air. The changes in FTIR spectra are given in Fig. 4. It seems in particular that the shape of carbonyl absorbance is the same for all stabilizer packages under study, contrarily to PP case for example where the carbonyl absorbance observed in thermally oxidized samples is not the same for phenols and HAS stabilized samples [14,15]. It suggests that the same stable carbonyl products are generated during thermal oxidation and the same molar absorptivity can be used for all samples under study. Using these data, the carbonyl concentration is measured during ageing, results at $50{ }^{\circ} \mathrm{C}$ are shown in Fig. 5 .

Those curves display the characteristic behavior for the oxidation of pure and stabilized hydrocarbon polymers i.e. an induction period during (which there are low changes for example in the concentration in carbonyls) followed by a strong auto-acceleration characterized by the maximal oxidation rate. Let us recall that, according to previous works in PDCPD [12] or other polyolefins [16], the end of induction period (in terms of carbonyl build-up) corresponds to the loss of mechanical toughness (for example a drop in elongation at break), in other words to end-of-life (NB: a more thorough investigation will be presented in Ref. [17]). For better illustrating the effect of stabilizer concentration, the changes of oxidation rate and lifetime with concentration of stabilizers are summarized in Fig. 6.

These experimental results call for the following comments:

- The use of commercial stabilizers induces a large increase in lifetime (or induction period for carbonyl build-up, see above) of PDCPD: for an example lifetime of PDCPD with $0.01 \mathrm{~mol} \mathrm{l}^{-1}$ of Tinuvin 123 at $50{ }^{\circ} \mathrm{C}$ is equal to $400 \mathrm{~h}$ vs $3 \mathrm{~h}$ for unstabilized PCDPD in the same conditions.

- The lifetime (or induction period) increases with stabilizer concentration. In the case of Tinuvin 123, two regimes can be distinguished: the "low concentrations" domain where induction period linearly increases with the concentration of stabilizers (consistently with previous observations [18-20]) and the "high concentrations" domain where the lifetime increases at a slower rate (or even almost plateaus). A possible explanation for the existence of those two domains is that stabilizer concentration becomes higher than its solubility limit (this latter is defined as the concentration above which stabilizer starts to 

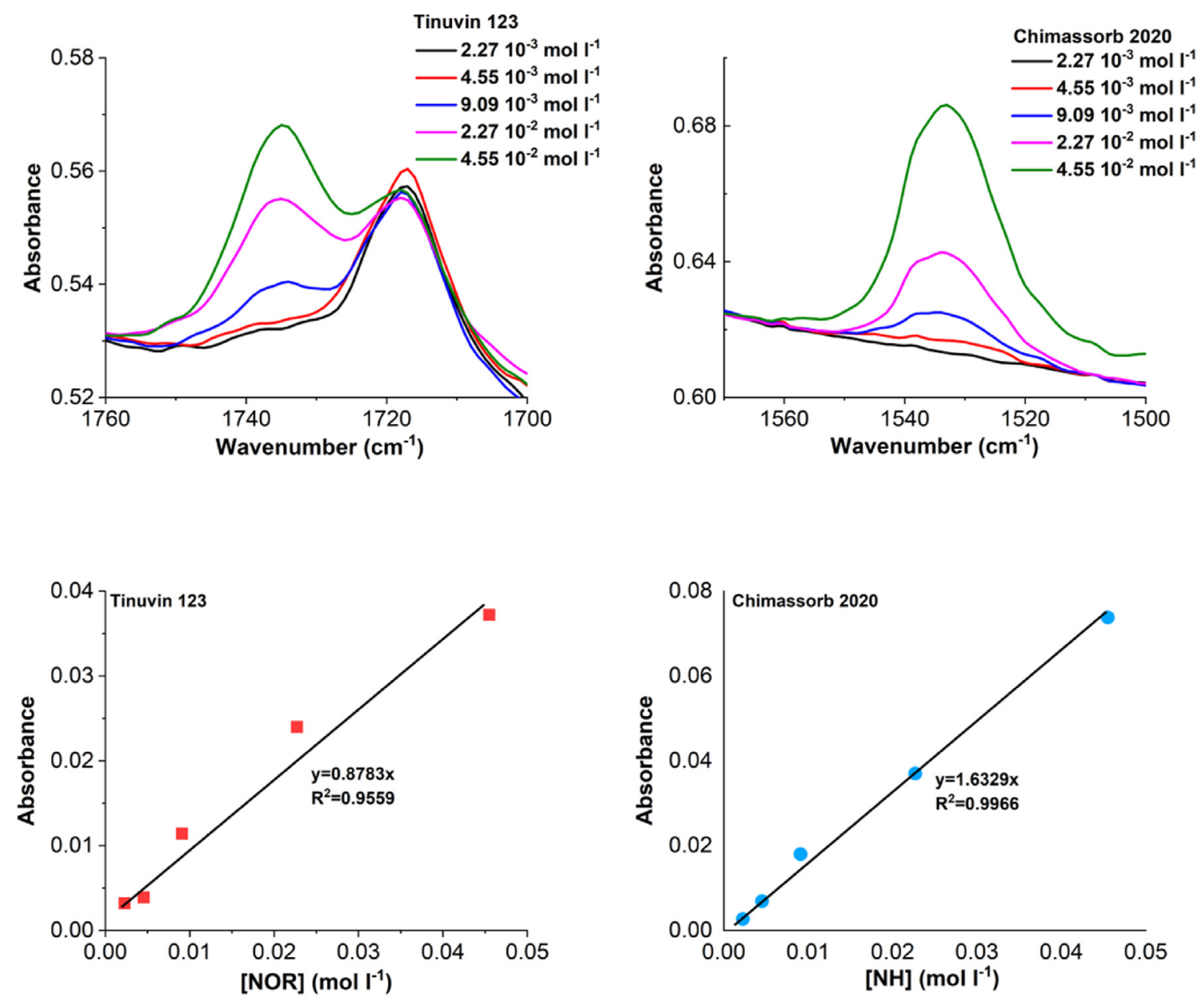

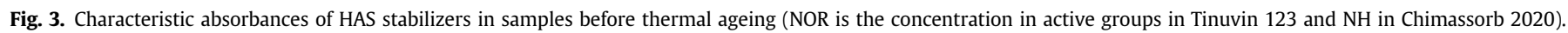

phase separate [21] and excess stabilizer concentration has low effect [13]). No insoluble stabilizer was detected in liquid monomer suggesting that compatibility was good (this was not verified in the polymer however). Another possible explanation is linked to the stabilizer evaporation [13] lowering its efficiency. In fact, when increasing ageing temperature, the value of Tinuvin 123 concentration separating the two domains remains the same (Fig. 6) whereas both the solubility limit and the evaporation rate are expected to increase [22,23] with respectively a positive or a negative effect on the concentration separating "low" and "high concentration" domains. It suggests that both effects co-exist and perhaps compensate.

- The oxidation rate decreases with the concentration of stabilizers and reaches a pseudo plateau. This behavior was already reported for hindered amines [24,25] consistently with their regenerative behavior. In the case of phenolic antioxidants, an increase in the stabilizer concentration leads to shift kinetic curves towards longer exposure times [18-20,26] without significant changes in oxidation rate when increasing the stabilizer concentration. It suggests that some regenerative processes also occur for BHT, as it will be discussed latter.

- The phenolic stabilizer BHT is less efficient than Tinuvin 123 (possibly because Hindered Amines display a regenerative behavior where phenols display a sacrificial one). Despite its lower molar mass (involving possibly evaporation issues), Tinuvin 123 seems more efficient than Chimassorb 2020 (which is an oligomer and cannot migrate or evaporate). A mechanistic explanation will be proposed in the discussion. Quite interestingly, BHT seems less efficient than Tinuvin 123 but the gap decreases with temperature in good agreement with previously reported results in polyolefins where HALS are considered as efficient stabilizers for low temperature thermal ageing $[27,28]$.

\section{Discussion}

Our aim here is to describe the effect of antioxidants using a kinetic model for lifetime prediction for stabilized PDCPD. For that purpose, we will complete the previously established model which is validated for unstabilized thin films of PDCPD [12] by adding reactions describing the stabilization as illustrated for example in $[18,25,29,30]$. The associated kinetic constants will be assessed from fitting of experimental curves together with respect of their physical sense i.e. consistently with existing literature on radical processes.

\subsection{Kinetic modeling and strategy for estimating rate constants}

According to the literature [18,30,31], the action of phenolic antioxidants such as BHT during thermal oxidation could be described by the following reactions:

$$
(\mathrm{S} 1) \mathrm{POO}^{\circ}+\mathrm{AH} \rightarrow \mathrm{POOH}+\mathrm{A}^{\circ} \quad \mathrm{k}_{\mathrm{S} 1}
$$


(S2) $\mathrm{POO}^{\circ}+\mathrm{A}^{\circ} \rightarrow$ inactive product

$\mathrm{k}_{\mathrm{S} 2}$

Those reactions compete with the propagation reaction involving $\mathrm{POO}^{\circ}$ such as $\mathrm{POO}^{\circ}+\mathrm{PH} \rightarrow \mathrm{POOH}+\mathrm{P}^{\circ}$. The generated $\mathrm{POOH}$ during the reaction (3) decomposes as described in literature: $\mathrm{POOH} \rightarrow \mathrm{PO}^{\circ}+{ }^{\circ} \mathrm{OH}$. Thus, reactions (S1) and (S2) consume 2 $\mathrm{POO}^{\circ}$ radicals and create 2 radicals $\left(\mathrm{PO}^{\circ}\right.$ and $\left.{ }^{\circ} \mathrm{OH}\right)$. In the absence of phenols, one $\mathrm{POO}^{\circ}$ radical gives a $\mathrm{P}^{\circ}$ and a $\mathrm{POOH}$ i.e. 3 radicals in the end. This explains why phenols are efficient stabilizers.

In fact, as it will be seen later, this simple model gives acceptable simulations for hydrocarbon polymers [18,30,31] but failed in PDCPD in particular in simulating the decrease of oxidation rate with hindered phenol concentration. Basing on Pospisil's work [32], several hypotheses for partial regeneration of hindered phenols were tested:

$$
\begin{array}{ll}
\mathrm{A}^{\circ}+\mathrm{P}^{\circ} \rightarrow \mathrm{AH}+\mathrm{P}^{\circ} & \mathrm{k}_{\mathrm{S} 3} \\
\mathrm{~A}^{\circ}+\mathrm{A}^{\circ} \rightarrow \mathrm{AH}+\text { inactive products } & \mathrm{k}_{\mathrm{S} 4}
\end{array}
$$

In this case, however, neither $\mathrm{k}_{\mathrm{S} 1}$ nor $\mathrm{k}_{\mathrm{S} 3}$ or $\mathrm{k}_{\mathrm{S} 4}$ are a priori known.

Basing on the literature [33], the following two reactions seem to describe the action of Tinuvin 123:

$$
\begin{aligned}
& (\mathrm{N} 5)>\mathrm{N}-\mathrm{O}^{\circ}+\mathrm{P}^{\circ} \rightarrow>\mathrm{N}-\mathrm{O}-\mathrm{P} \quad \mathrm{k}_{\mathrm{N} 5} \\
& (\mathrm{~N} 6)>\mathrm{N}-\mathrm{O}-\mathrm{P}+\mathrm{POO}^{\circ} \rightarrow>\mathrm{N}-\mathrm{O}^{\circ}+\mathrm{POOH}+>\mathrm{C} \\
& =\mathrm{C}<\quad \mathrm{k}_{\mathrm{N} 6}
\end{aligned}
$$

In the case of amine stabilizers such as Chimassorb 2020, the "active" forms of stabilizers (nitroxy and alkoxyl amine) are generated from $>\mathrm{N}-\mathrm{H}$ groups. Despite some controversies, it seems that the following mechanism based on the Faucitano's work $[34,35]$ can be employed [36]:

$$
\begin{aligned}
& (\mathrm{N} 1)>\mathrm{N}-\mathrm{H}+\mathrm{POO}^{\circ} \rightarrow>\mathrm{N}^{\circ}+\mathrm{POOH} \quad \mathrm{k}_{\mathrm{N} 1} \\
& (\mathrm{~N} 2)>\mathrm{N}-\mathrm{H}+\mathrm{O}_{2} \rightarrow>\mathrm{N}^{\circ}+\mathrm{HOO} \quad \mathrm{k}_{\mathrm{N} 2} \\
& (\mathrm{~N} 3)>\mathrm{N}^{\circ}+\mathrm{O}_{2} \rightarrow>\mathrm{N}-\mathrm{O}-\mathrm{O}^{\circ} \quad \mathrm{k}_{\mathrm{N} 3} \\
& (\mathrm{~N} 4)>\mathrm{N}-\mathrm{O}-\mathrm{O}^{\circ}+>\mathrm{N}-\mathrm{O}-\mathrm{O}^{\circ} \rightarrow 2>\mathrm{N}-\mathrm{O}^{\circ}+\mathrm{O}_{2} \quad \mathrm{k}_{\mathrm{N} 4} \\
& \text { (N5) }>\mathrm{N}-\mathrm{O}^{\circ}+\mathrm{P}^{\circ} \rightarrow>\mathrm{N}-\mathrm{O}-\mathrm{P} \quad \mathrm{k}_{\mathrm{N} 5} \\
& (\mathrm{~N} 6)>\mathrm{N}-\mathrm{O}-\mathrm{P}+\mathrm{POO}^{\circ} \rightarrow>\mathrm{N}-\mathrm{O}^{\circ}+\mathrm{POOH}+>\mathrm{C} \\
& =\mathrm{C}<\mathrm{k}_{\mathrm{N} 6}
\end{aligned}
$$

Those reactions were added to the mechanistic scheme established for additive free PDCPD $\left[{ }^{12}\right]$ :

$$
\begin{array}{lc}
\mathrm{POOH} \rightarrow 2 \mathrm{P}^{\circ}+\gamma_{1} \mathrm{P}=\mathrm{O} & \mathrm{k}_{\mathrm{lu}} \\
\mathrm{POOH}+\mathrm{POOH} \rightarrow \mathrm{P}^{\circ}+\mathrm{POO}^{\circ}+\gamma_{1} \mathrm{P}=\mathrm{O} & \mathrm{k}_{\mathrm{lb}} \\
\mathrm{POOH}+\mathrm{HY} \rightarrow \mathrm{H}_{2} \mathrm{O}+2 \mathrm{P}^{\circ}+\mathrm{HY} & \mathrm{k}_{\mathrm{lc}} \\
\mathrm{P}^{\circ}+\mathrm{O}_{2} \rightarrow \mathrm{POO}^{\circ} & \mathrm{k}_{2} \\
\mathrm{POO}^{\circ}+\mathrm{PH} \rightarrow \mathrm{POOH}+\mathrm{P}^{\circ} & \mathrm{k}_{3}
\end{array}
$$

$$
\begin{aligned}
& (\mathrm{A}-1) \mathrm{P}^{\circ}+>\mathrm{C}=\mathrm{C}<\rightarrow \text { crosslinking }+\mathrm{P}^{\circ} \quad \mathrm{k}_{\mathrm{a} 1} \\
& (\mathrm{~A}-2) \mathrm{POO}^{\circ}+>\mathrm{C}=\mathrm{C}<\rightarrow \gamma_{1} \mathrm{P}=\mathrm{O}+\mathrm{P}^{\circ} \quad \mathrm{k}_{\mathrm{a} 2} \\
& \mathrm{P}^{\circ}+\mathrm{P}^{\circ} \rightarrow \gamma_{4} \text { crosslinking }+\left(1-\gamma_{4}\right)>\mathrm{C}=\mathrm{C}<+(1 \\
& \left.-\gamma_{4}\right) \mathrm{PH} \\
& \mathrm{P}^{\circ}+\mathrm{POO}^{\circ} \rightarrow \gamma_{5} \mathrm{POOP}+\gamma_{5} \text { crosslinking }+\left(1-\gamma_{5}\right) \mathrm{POOH} \\
& +\left(1-\gamma_{5}\right)>\mathrm{C}=\mathrm{C}<\quad \mathrm{k}_{5} \\
& \mathrm{POO}^{\circ}+\mathrm{POO}^{\circ} \rightarrow \mathrm{P}=\mathrm{O}+\mathrm{POH} \quad \mathrm{k}_{6}
\end{aligned}
$$

The kinetic model was modified to take into account the effect either of phenols, HAS of alkoxyamine type (Tinuvin 123) or amine (Chimassorb 2020) by changing differential equations as shown in Appendix 2.

The Thickness of Oxidized Layer is given by $\mathrm{TOL}^{2}=\mathrm{D}_{\mathrm{O}_{2}}\left[\mathrm{O}_{2}\right] / \mathrm{r}_{\mathrm{OX}}$ (TOL, $\mathrm{D}_{\mathrm{O} 2},\left[\mathrm{O}_{2}\right], \mathrm{r}_{\mathrm{OX}}$ being respectively the, the oxygen diffusivity, its solubility in polymer, and the oxidation rate in surface). Presumably $\left(\mathrm{D}_{\mathrm{O} 2}\right)_{\text {stabilized }}=\left(\mathrm{D}_{\mathrm{O} 2}\right)_{\text {pure, }},\left[\mathrm{O}_{2}\right]_{\text {stabilized }}=\left[\mathrm{O}_{2}\right]_{\text {pure}}$, and $\left(\mathrm{r}_{\mathrm{OX}}\right)_{\text {stabilized }}<\left(\mathrm{r}_{\mathrm{OX}}\right)_{\text {pure, }}$, we have $\mathrm{TOL}_{\text {stabilized }}>\mathrm{TOL}_{\text {pure }}$. NB: "pure" subscript corresponds to additive-free PDCPD. In other words, the oxidation is supposed to be homogeneous in thickness so that the diffusion terms for stabilizers were neglected. The rate constants $\mathrm{k}_{1 \mathrm{u}} \ldots \mathrm{k}_{6}$ were previously determined for pure PDCPD and remain valid without any restriction [12]. In other words, the values for stabilization rate constants $\left(\mathrm{k}_{\mathrm{S} 1}, \mathrm{k}_{\mathrm{S} 2}, \mathrm{k}_{\mathrm{N} 1} \ldots \mathrm{k}_{\mathrm{N} 6}\right)$ are the "only" missing parameters for simulating experimental results.

\subsection{Strategy for estimating rate constants}

In principle, there might be an infinite number of set of (missing) rate constants for stabilization reactions $\left(\mathrm{k}_{\mathrm{S} 1}, \mathrm{k}_{\mathrm{S} 2}, \mathrm{k}_{\mathrm{N} 1} \ldots\right.$ $\mathrm{k}_{\mathrm{N} 6}$ ) allowing a simulation of experimental results. We decided to fix some values from literature (either from polyolefins or model liquid compounds stabilization) in the case where it seemed to us there was no objection to use them in PDCPD.

For the stabilization by BHT and hindered phenols, the reaction (S2) is expected to be fast since it involves 2 radicals. According to data compiled by Denisov [37], $\mathrm{k}_{\mathrm{s} 2}$ ranges from $1.7 \times 10^{8}$ to $4.2 \times 10^{8}$ depending on the para substituent of phenol. In our case, the $\mathrm{k}_{\mathrm{s} 2}$ value was chosen equal to $10^{8}$ whatever the ageing temperature. It seems also that the activation energy of such a fast reaction would be close to $0 . \mathrm{k}_{\mathrm{S} 1}$ values are thus the only adjustable parameter and will be determined by an inverse approach. Some reported values of $\mathrm{k}_{\mathrm{S} 1}$ for comparable polymers are summarized in Table 2. It was also observed that $E_{\mathrm{S} 1} \geq \mathrm{E}_{3}$ consistently with the matter that Bond Dissociation Energy for broken $\mathrm{O}-\mathrm{H}$ bond in phenols is higher than for $\mathrm{C}-\mathrm{H}$ bond in $\mathrm{PE}$ or PP and certainly in PDCPD.

For stabilization by Tinuvin 123 and Chimassorb 2020, $\mathrm{k}_{\mathrm{N} 5}$ (for reaction $>\mathrm{NO}^{\circ}+\mathrm{P}^{\circ}$ ) value is supposed to be very high as observed for model compounds [38,39]. Bauer and Gerlock [40] have also reported that $\mathrm{k}_{\mathrm{N} 5}$ and $\mathrm{k}_{2}$ (rate constant for $\mathrm{P}^{\circ}+\mathrm{O}_{2}$ ) have the same order of magnitude (about $10^{8}-10^{9} 1 \mathrm{~mol}^{-1} \mathrm{~s}^{-1}$ ). It seems also that $\mathrm{k}_{\mathrm{N} 5}$ is clearly higher than $\mathrm{k}_{\mathrm{N} 6}$ (because the reaction between $>\mathrm{N}-\mathrm{O}^{\circ}$ and $\mathrm{P}^{\circ}$ is expected to be faster than the reaction between $\mathrm{POO}^{\circ}$ and $>\mathrm{N}$-O-P which is quite stable). Some kinetic parameters from the literature are summarized in Table 3 . For Tinuvin $123, \mathrm{k}_{\mathrm{N} 5}$ was hence fixed at $10^{9} \mathrm{l} \mathrm{mol}^{-1} \mathrm{~s}^{-1}$ and $\mathrm{k}_{\mathrm{N} 6}$ was thus adjusted by curves best fitting.

The mechanisms of reactions (N5) and (N6) are the same for Tinuvin 123 and Chimassorb 2020, and the corresponding rate 


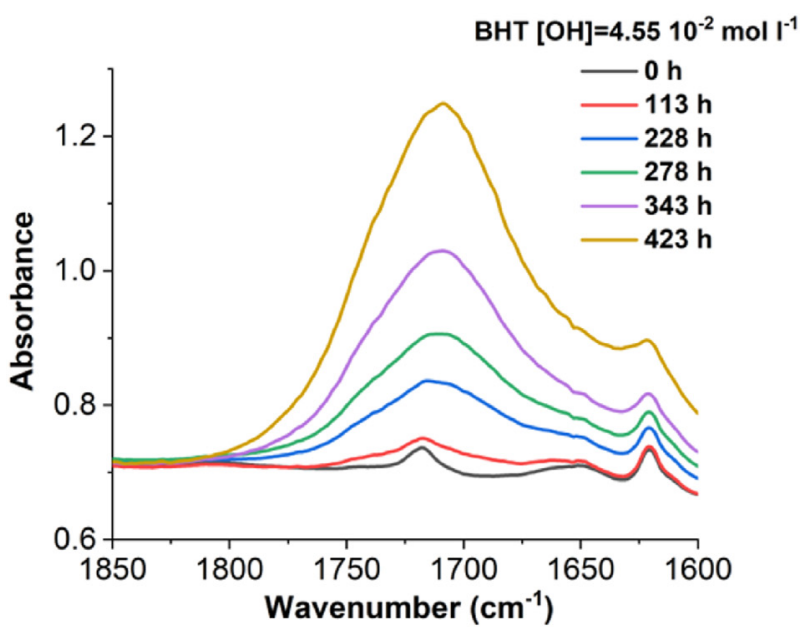

(a)

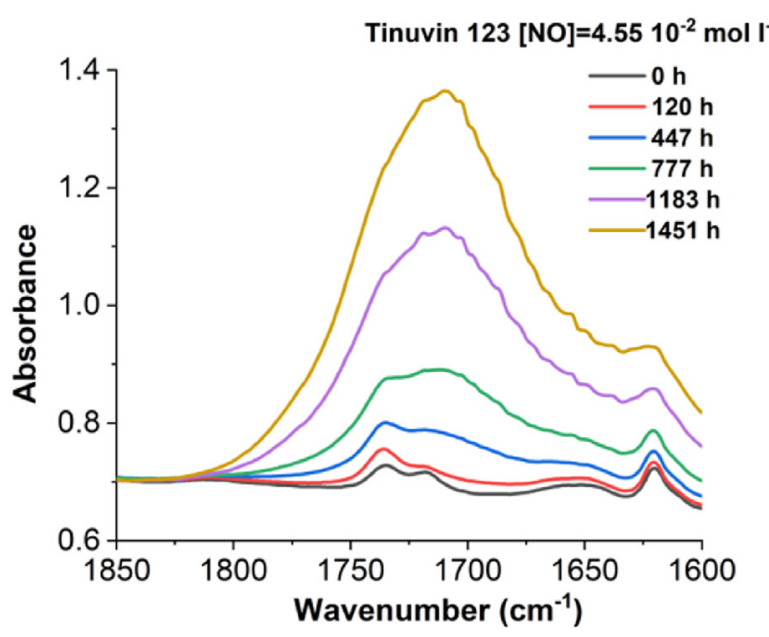

(b)

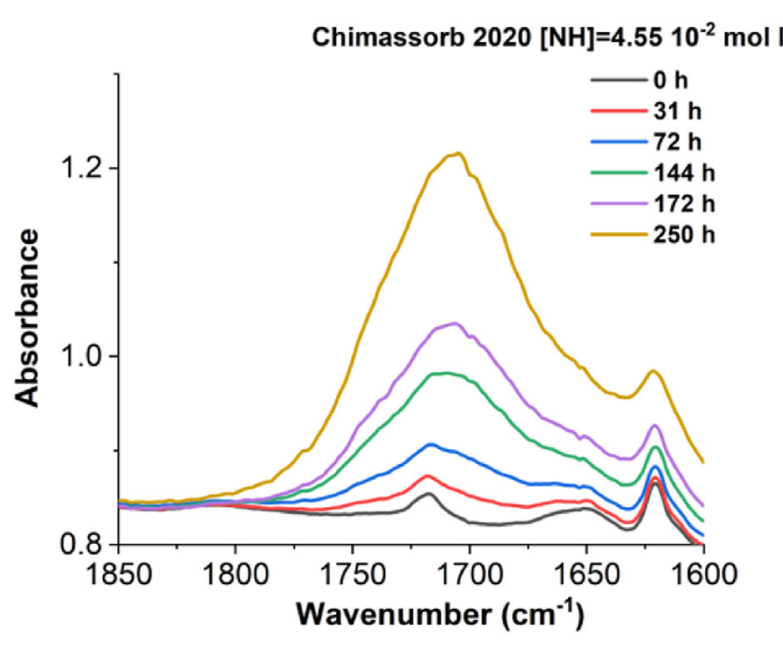

(c)

Fig. 4. FTIR spectra of samples after various ageing times at $50{ }^{\circ} \mathrm{C}$ for BHT (a), Tinuvin 123 (b) and Chimassorb 2020 (c).

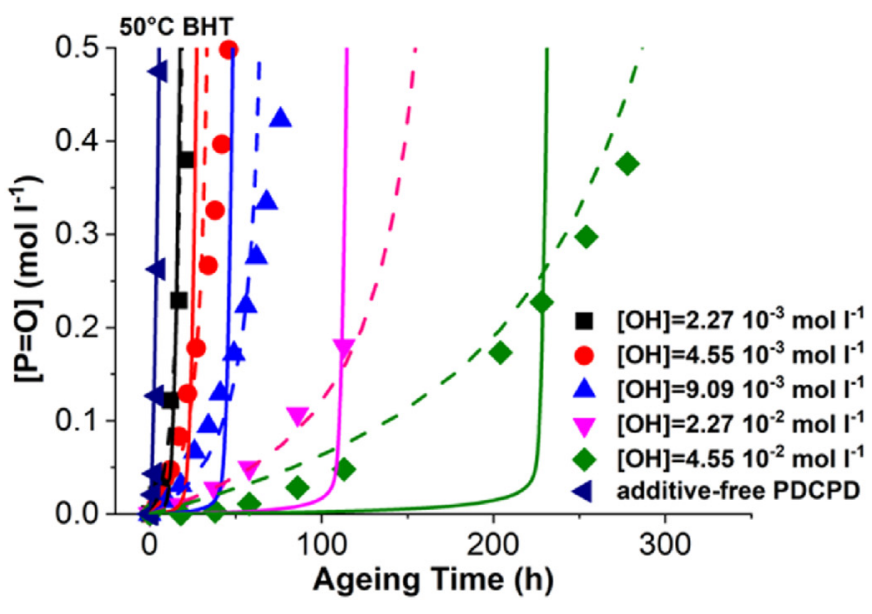

(a)

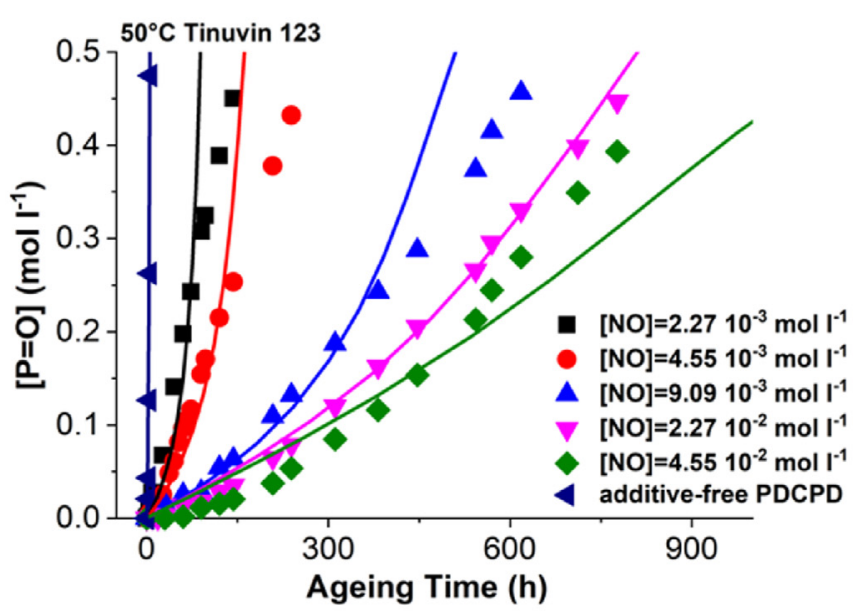

(b)

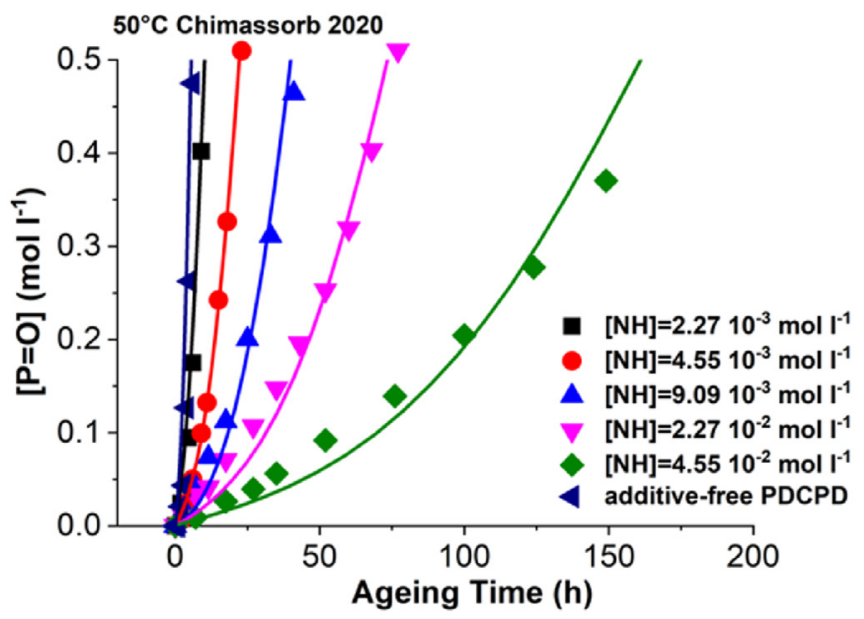

(c)

Fig. 5. Kinetic curves of the carbonyl concentration $([\mathrm{P}=\mathrm{O}])$ as a function of the exposure time for PDCPD stabilized with 5 concentrations of BHT (a), Tinuvin 123 (b) and Chimassorb 2020 (c) and additive-free PDCPD at $50{ }^{\circ} \mathrm{C}$. Solid lines represent simulations by kinetic model (see "Discussion" with dashed lines for model 1 and full lines for model 2). 

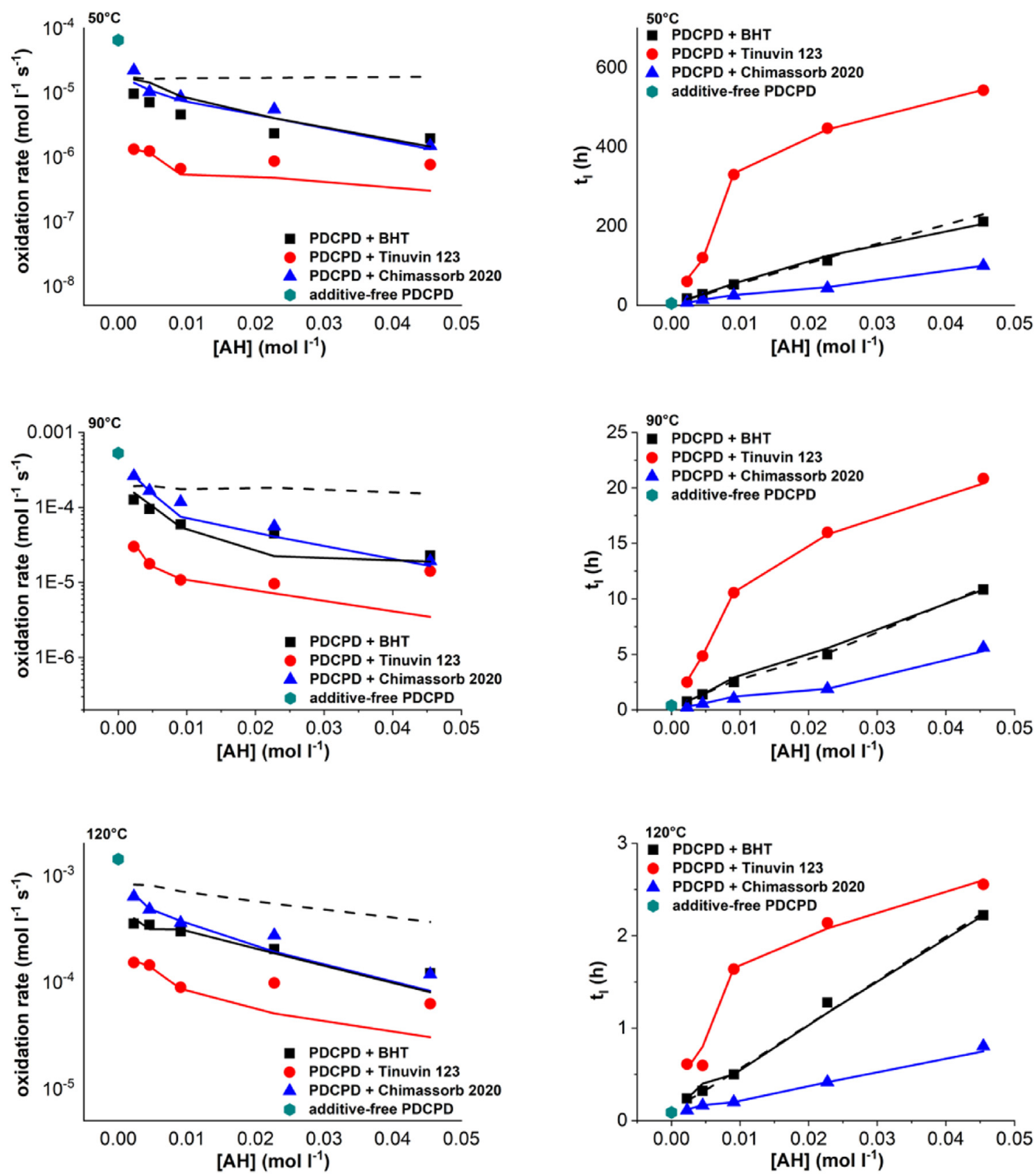

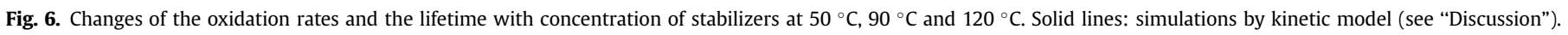

Table 2

Kinetic parameters used in literature.

\begin{tabular}{|c|c|c|c|c|}
\hline & PP [18] & PE [31] & Model compounds [37] & PB [30] \\
\hline $\mathrm{k}_{\mathrm{s} 1}\left(1 \mathrm{~mol}^{-1} \mathrm{~s}^{-1}\right)$ & $40\left(80^{\circ} \mathrm{C}\right)$ & $4 \times 10^{4}\left(110^{\circ} \mathrm{C}\right)$ & 1 & $3\left(100{ }^{\circ} \mathrm{C}\right)$ \\
\hline $\mathrm{E}_{\mathrm{s} 1}\left(\mathrm{~kJ} \mathrm{~mol}^{-1}\right)$ & $70 \pm 10$ & 80 & l & 1 \\
\hline $\mathrm{k}_{\mathrm{s} 1} / \mathrm{k}_{3}$ & $635\left(80^{\circ} \mathrm{C}\right)$ & $2 \times 10^{4}\left(110^{\circ} \mathrm{C}\right)$ & 1 & $2\left(100{ }^{\circ} \mathrm{C}\right)$ \\
\hline $\mathrm{k}_{\mathrm{s} 2}\left(1 \mathrm{~mol}^{-1} \mathrm{~s}^{-1}\right)$ & $10^{6}$ & $5 \times 10^{8}\left(110^{\circ} \mathrm{C}\right)$ & $(1.7-4.2) \times 10^{8}$ & $10^{5}\left(100^{\circ} \mathrm{C}\right)$ \\
\hline $\mathrm{E}_{\mathrm{s} 2}$ & 0 & 0 & 1 & 0 \\
\hline
\end{tabular}

constants will be considered the same for both stabilizers (and presumably all the other members of the HAS family). As previously reported [23], $\mathrm{k}_{\mathrm{N} 2}$ (rate constant for oxygen $\mathrm{O}_{2}+$ labile hydrogen of $\mathrm{NH}$ ) is low and was reported on the order of $10^{-4} 1 \mathrm{~mol}^{-1} \mathrm{~s}^{-1}$ at
$110{ }^{\circ} \mathrm{C}$. Last, $\mathrm{k}_{\mathrm{N} 3}$ and $\mathrm{k}_{\mathrm{N} 4}$ are certainly high (they correspond to radical processes) and it was proposed that $\mathrm{k}_{\mathrm{N} 3}=\mathrm{k}_{\mathrm{N} 4}=10^{6} 1 \mathrm{~mol}^{-1} \mathrm{~s}^{-1}$. 
Table 3

Kinetic parameters from literature.

\begin{tabular}{lll}
\hline & Model compounds [38,39] & PE [25] \\
\hline $\mathrm{k}_{\mathrm{N} 5}\left(1 \mathrm{~mol}^{-1} \mathrm{~s}^{-1}\right)$ & $2 \times 10^{7}-2 \times 10^{9}\left(18-24^{\circ} \mathrm{C}\right)$ & $10^{10}\left(110^{\circ} \mathrm{C}\right)$ \\
\hline & Acrylic-urethane [40] & PE [25] \\
\hline $\mathrm{k}_{\mathrm{N} 6}\left(1 \mathrm{~mol}^{-1} \mathrm{~s}^{-1}\right)$ & $(2.3-4.6) \times 10^{-1}\left(25^{\circ} \mathrm{C}\right)$ & $7 \times 10^{3}\left(110^{\circ} \mathrm{C}\right)$ \\
$\mathrm{k}_{\mathrm{N} 5} / \mathrm{k}_{3}$ & $/$ & $4118\left(110^{\circ} \mathrm{C}\right)$ \\
\hline
\end{tabular}

\subsection{Simulation of the experimental results}

The system of differential equations derived from the kinetic scheme can be resolved using Matlab solver (ODE23s) with rate constants given in Appendix 2 for pure PDCD, initial conditions given in Table 4, and kinetic parameters for stabilization determined as explained in the previous paragraph. The corresponding simulations are given in Fig. 5 for $50{ }^{\circ} \mathrm{C}$ and 6 for the other temperatures. These results call for the following comments:

(1) For PDCPD stabilized with BHT, the "classical" model (reactions S1 and S2) failed to simulate the maximal oxidation rate for carbonyl build up and only gave acceptable simulation for lifetime. Basing on the hypothesis that phenols can regenerate by dismutation process (involving conjugated species $\left[{ }^{32}\right]$ ), results were successfully simulated using a completed version of the model:

$\begin{array}{lc}\mathrm{POO}^{\circ}+\mathrm{AH} \rightarrow \mathrm{POOH}+\mathrm{A}^{\circ} & \mathrm{k}_{\mathrm{S} 1} \\ \mathrm{POO}^{\circ}+\mathrm{A}^{\circ} \rightarrow \text { inactive products } & \mathrm{k}_{\mathrm{S} 2} \\ \mathrm{~A}^{\circ}+\mathrm{P}^{\circ} \rightarrow \mathrm{AH}+\text { inactive products } & \mathrm{k}_{\mathrm{S} 3}\end{array}$

The reaction S3 is actually favored by the conjugation of alkyl radicals but we must acknowledge this alternative model is not fully validated. It was observed that model simulates experimental results only if $\mathrm{k}_{\mathrm{S} 2} \ll \mathrm{k}_{\mathrm{S} 3}$. A possible set of rate constants is given in Table 5 a but it remains to conclude on its unicity. In further studies, the measurements of BHT residual concentration with ageing time should be conducted for better identifying the stabilization rate constants.

(2) For PDCPD stabilized with Tinuvin 123 and Chimassorb 2020, model simulates fairly the accumulation of carbonyl groups at $50{ }^{\circ} \mathrm{C}, 90^{\circ} \mathrm{C}$ and $120^{\circ} \mathrm{C}$ irrespectively of the stabilizer concentration. This is a quite encouraging result given the relative complexity of HAS stabilization.

The kinetic parameters estimated from inverse approach are summarized in Table $5 \mathrm{~b}$. The adjusted parameters ( $\mathrm{k}_{\mathrm{N} 6}$ for Tinuvin 123, and later $\mathrm{k}_{\mathrm{N} 1}$ for Chimassorb 2020) are well in line with literature value through for example $\mathrm{k}_{\mathrm{N} 6} / \mathrm{k}_{3}$ ratio. As expected, the model simulates degradation kinetics for Tinuvin 123 and
Table 5

Rate constants describing action of BHT (a) and Tinuvin 123 and Chimassorb 2020 (b). NB: for Tinuvin $123, \mathrm{k}_{\mathrm{N} 5}$ adjusted from literature, $\mathrm{k}_{\mathrm{N} 6}$ adjusted for fitting data, and for Chimassorb 2020, $\mathrm{k}_{\mathrm{N} 5}$, $\mathrm{k}_{\mathrm{N} 6}$ were taken from the value of Tinuvin $123, \mathrm{k}_{\mathrm{N} 1}, \mathrm{k}_{\mathrm{N} 2}$, $\mathrm{k}_{\mathrm{N} 3}$ adjusted for fitting data (see text).

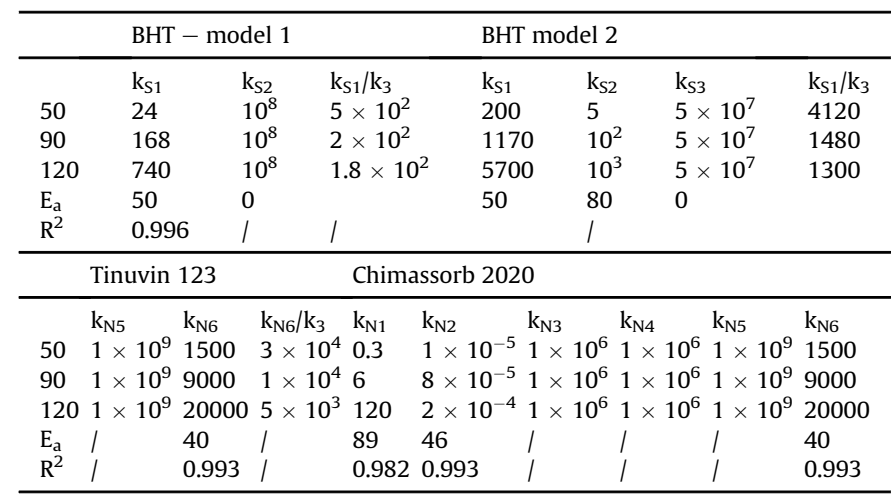

Chimassorb 2020 with the same $\mathrm{k}_{\mathrm{N} 5}$ and $\mathrm{k}_{\mathrm{N} 6}$, suggesting an "universal" set of values for the Denisov's cycle (in a given polymer family) for all member family. Interestingly, this $\mathrm{k}_{\mathrm{N} 5}$, $\mathrm{k}_{\mathrm{N} 6}$ set seems also to allow a description for one given sample of PDPCD stabilized with TEMPO (Appendix 3) which confirms this last statement.

Since kinetic model reasonably fits the experimental results for PDCPD stabilized with HAS, we were interested in using the kinetic model to discuss the differences between the two investigated HAS molecules. According simulations displayed in Fig. 7, Tinuvin 123 is present in its active form (alkoxyamine $>\mathrm{N}-\mathrm{O}-\mathrm{P}$ ) as soon as the beginning of exposure, and this form always predominates over $>\mathrm{N}-\mathrm{O}^{\circ}$ one. In Chimassorb 2020, it seems that the time to convert $>\mathrm{N}-\mathrm{H}$ into $>\mathrm{N}-\mathrm{O}-\mathrm{P}$ (approximately $30 \mathrm{~h}$ at $50^{\circ} \mathrm{C}$ ) limits HAS efficiency, the result of simulation being consistent with conclusions on other HAS molecules by Bauer and Gerlock [41]. Interestingly, it seems that during this "induction period", $\mathrm{POO}^{\circ}$ would accumulate at a very high level which explains why the maximal concentration in $>$ NOP is lower for Chimassorb 2020 than Tinuvin 123.

\section{Conclusions}

This paper addressed the thermal stabilization of PDCPD by phenolic and HAS stabilizers with the aim to propose stabilizers compatible with the ROMP polymerization and protecting efficiently the polymer for long term uses. Three antioxidants were chosen differing by their stabilization chemistry (phenol vs HAS), physical performances (oligomeric vs monomeric HAS) and amine functionalization (secondary amine vs alkoxylated one). Tinuvin 123 shows a better protection performance compared with BHT

Table 4

Initial conditions used in simulations of stabilized PDCPD oxidation.

\begin{tabular}{|c|c|c|c|}
\hline & BHT & Tinuvin 123 & Chimassorb 2020 \\
\hline$[\mathrm{POOH}]_{0}\left(\mathrm{~mol} \mathrm{l}^{-1}\right)$ & $5 \times 10^{-2}-1.5 \times 10^{-1}$ & $5 \times 10^{-2}-1.5 \times 10^{-1}$ & $5 \times 10^{-2}-1.5 \times 10^{-1}$ \\
\hline$[\mathrm{C}=\mathrm{C}]_{0}\left(\mathrm{~mol} \mathrm{l}^{-1}\right)$ & $8-9$ & $9-10$ & $8-9$ \\
\hline$[\mathrm{PH}]_{0}\left(\mathrm{~mol} \mathrm{l}^{-1}\right)$ & $16-18$ & $18-20$ & $16-18$ \\
\hline$\left[\mathrm{NO}^{\circ}\right]_{0}\left(\mathrm{~mol} \mathrm{l}^{-1}\right)$ & 1 & 0 & 0 \\
\hline$\left[\mathrm{O}_{2}\right]_{0}$ & $2.12 \times 10^{-3}$ & $2.12 \times 10^{-3}$ & $2.12 \times 10^{-3}$ \\
\hline$[\mathrm{NOP}]_{0}\left(\mathrm{~mol} \mathrm{l}^{-1}\right)$ & 1 & $2.27 \times 10^{-3}-4.55 \times 10^{-2}$ & 0 \\
\hline$[\mathrm{NH}]_{0}\left(\mathrm{~mol} \mathrm{l}^{-1}\right)$ & i & 1 & $2.27 \times 10^{-3}-4.55 \times 10^{-2}$ \\
\hline$\left[\mathrm{N}^{\circ}\right]_{0}\left(\mathrm{~mol} \mathrm{l}^{-1}\right)$ & i & i & 0 \\
\hline$\left[\mathrm{NOO}^{\circ}\right]_{0}\left(\mathrm{~mol} \mathrm{l}^{-1}\right)$ & 1 & i & 0 \\
\hline$\left[\mathrm{NO}^{\circ}\right]_{0}\left(\mathrm{~mol} \mathrm{l}^{-1}\right)$ & 1 & l & 0 \\
\hline$[\mathrm{AH}]_{0}\left(\mathrm{~mol} \mathrm{l}^{-1}\right)$ & $2.27 \times 10^{-3}-4.55 \times 10^{-2}$ & i & 1 \\
\hline$\left[\mathrm{A}^{\circ}\right]_{0}\left(\mathrm{~mol} \mathrm{l}^{-1}\right)$ & 0 & i & i \\
\hline
\end{tabular}




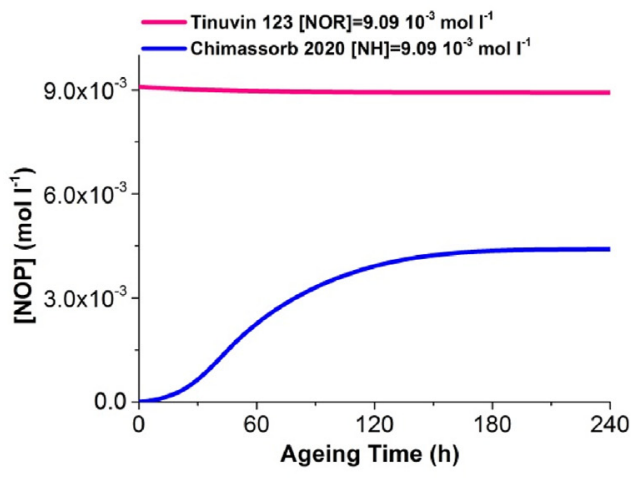

(a)

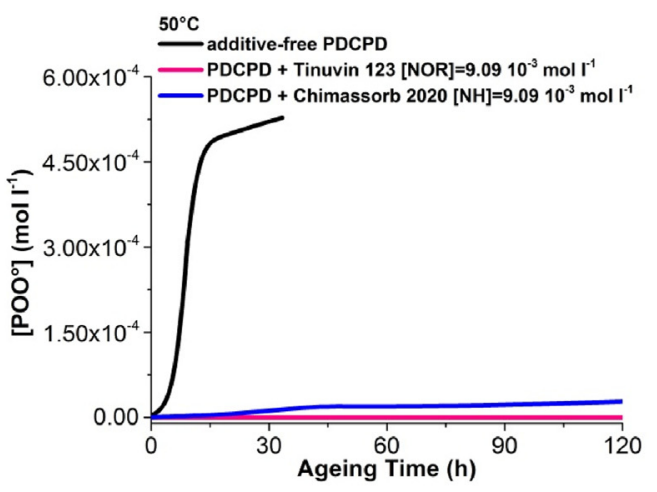

(b)

Fig. 7. Simulation curves of $>\mathrm{NOP}$ (a) and $\mathrm{POO}^{\circ}$ concentrations (b).

and Chimassorb 2020 especially when lowering the ageing temperature. It allows a remarkable extension of the lifetime and a decrease in the oxidation rate but physical loss might limit its efficiency. Even if both Tinuvin 123 and Chimassorb 2020 both are regenerative stabilizers, Chimassorb 2020 displays a limited performance in terms of anti-oxidation presumably due to the time needed to "activate" $>\mathrm{N}-\mathrm{H}$ groups. The kinetic model established for pure PDCPD was completed to simulate experimental results for the three investigated stabilizer molecules in a wide range of stabilizer concentration and ageing temperatures by adding elementary steps in line with previously published data for stabilization. In a close future, it must be completed to take into account the diffusion of stabilizers in bulky materials so as to help practitioners to make the best choice of stabilizers package.

\section{Acknowledgements}

Mr Christiano Santos is acknowledged for his help for experimental work. Agence Nationale de la Recherche is gratefully acknowledged for having funded this study (Project VRPOM Vieillissement des Réseaux Polymérisés par Métathèse 2016-2019).

\section{APPENDIX 1}

\section{APPENDIX 2}

1. Modified equations for PDCPD $+B H T$

$$
\begin{aligned}
\frac{d[\mathrm{POOH}]}{d t}= & -k_{1 u}[\mathrm{POOH}]-2 k_{1 b}[\mathrm{POOH}]^{2}+k_{3}\left[\mathrm{POO}^{\circ}\right][\mathrm{PH}] \\
& +k_{5}\left(1-\gamma_{5}\right)\left[\mathrm{P}^{\circ}\right]\left[\mathrm{POO}^{\circ}\right]+k_{s 1}\left[\mathrm{POO}^{\circ}\right][\mathrm{AH}] \\
\frac{d\left[\mathrm{POO}^{\circ}\right]}{d t}= & k_{1 b}\left[\mathrm{POOH}^{2}+k_{2}\left[\mathrm{P}^{\circ}\right]\left[\mathrm{O}_{2}\right]-k_{3}\left[\mathrm{POO}^{\circ}\right][\mathrm{PH}]-k_{5}\left[\mathrm{P}^{\circ}\right]\left[\mathrm{POO}^{\circ}\right]\right. \\
& -2 k_{6}\left[\mathrm{POO}^{\circ}\right]^{2}-k_{a 2}\left[\mathrm{POO}^{\circ}\right][\mathrm{C}=\mathrm{C}]-k_{s 1}\left[\mathrm{POO}^{\circ}\right][\mathrm{AH}] \\
& -k_{\mathrm{s} 2}\left[\mathrm{POO}^{\circ}\right]\left[\mathrm{A}^{\circ}\right]
\end{aligned}
$$

Equations for $\mathrm{d}\left[\mathrm{P}^{\circ}\right] / \mathrm{dt}$ and $\mathrm{d}[>\mathrm{C}=\mathrm{C}<] / \mathrm{dt}$ are unchanged.

Then, two new equations related to $\mathrm{AH}$ and $\mathrm{A}^{\circ}$ should be added in the case of thin samples

$\frac{\partial[A H]}{\partial t}=-k_{S 1}\left[P O O^{\circ}\right][A H]+D_{A H} \frac{\partial^{2}[A H]}{\partial x^{2}}$

$\frac{\partial\left[A^{\circ}\right]}{\partial t}=k_{S 1}\left[P O O^{\circ}\right][A H]-k_{S 2}\left[P O O^{\circ}\right]\left[A^{\circ}\right]+D_{A H} \frac{\partial^{2}[A H]}{\partial x^{2}}$

Where $\mathrm{D}_{\mathrm{AH}}$ is the diffusion coefficient of the stabilizer. Since the thin films were used for studying thermal oxidation of stabilized PDCPD, the item with $\boldsymbol{D}_{\boldsymbol{A H}}$ should be neglected.

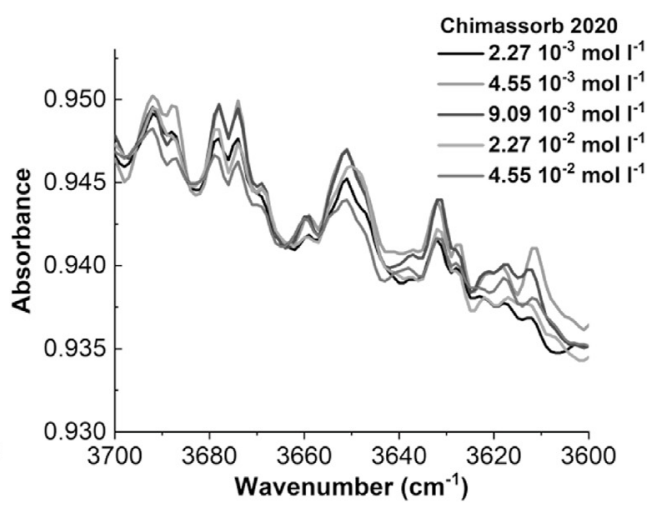

Fig. 8. FTIR spectra in the $\mathrm{O}-\mathrm{H}$ or $\mathrm{N}-\mathrm{H}$ region for virgin PDCPD + BHT (a) and PDCPD + Chimassorb 2020 (b) 


$$
\begin{aligned}
\frac{d\left[P^{\circ}\right]}{d t}= & 2 k_{1 u}[\mathrm{POOH}]+k_{1 b}[\mathrm{POOH}]^{2}-k_{2}\left[\mathrm{P}^{\circ}\right]\left[\mathrm{O}_{2}\right]+k_{3}\left[\mathrm{POO}^{\circ}\right][\mathrm{PH}] \\
& -2 k_{4}\left[\mathrm{P}^{\circ}\right]^{2}-k_{5}\left[\mathrm{P}^{\circ}\right]\left[\mathrm{POO}^{\circ}\right]+k_{a 2}\left[\mathrm{POO}^{\circ}\right][\mathrm{C}=\mathrm{C}] \\
& -k_{N 1}\left[\mathrm{NO}^{\circ}\right]\left[\mathrm{P}^{\circ}\right]
\end{aligned}
$$

$$
\begin{aligned}
\frac{d\left[\mathrm{POO}^{\circ}\right]}{d t}= & k_{1 b}[\mathrm{POOH}]^{2}+k_{2}\left[\mathrm{P}^{\circ}\right]\left[\mathrm{O}_{2}\right]-k_{3}\left[\mathrm{POO}^{\circ}\right][\mathrm{PH}]-k_{5}\left[\mathrm{P}^{\circ}\right]\left[\mathrm{POO}^{\circ}\right] \\
& -2 k_{6}\left[\mathrm{POO}^{\circ}\right]^{2}-k_{a 2}\left[\mathrm{POO}^{\circ}\right][\mathrm{C}=\mathrm{C}]-k_{N 2}[N-O-P]\left[\mathrm{POO}^{\circ}\right]
\end{aligned}
$$

$$
\begin{aligned}
\frac{d[\mathrm{POOH}]}{d t}= & -k_{1 u}[\mathrm{POOH}]-2 k_{1 b}[\mathrm{POOH}]^{2}+k_{3}\left[\mathrm{POO}^{\circ}\right][\mathrm{PH}] \\
& +k_{5}\left(1-\gamma_{5}\right)\left[\mathrm{P}^{\circ}\right]\left[\mathrm{POO}^{\circ}\right]+k_{\mathrm{N} 2}[N-\mathrm{O}-\mathrm{P}]\left[\mathrm{POO}^{\circ}\right]
\end{aligned}
$$

$$
\begin{array}{r}
\frac{d[C=C]}{d t}=-k_{a 1}\left[P^{\circ}\right][C=C]-k_{a 2}\left[P O O^{\circ}\right][C=C]+\left(1-\gamma_{4}\right) k_{4}\left[P^{\circ}\right]^{2} \\
+\left(1-\gamma_{5}\right) k_{5}\left[P^{\circ}\right]\left[P O O^{\circ}\right]+k_{N 2}[N-O-P]\left[P O O^{\circ}\right]
\end{array}
$$

Then two equations about the stabilizers will be added:

$$
\begin{aligned}
& \frac{d\left[N O^{\circ}\right]}{d t}=-k_{N 1}\left[N O^{\circ}\right]\left[P^{\circ}\right]+k_{N 2}[N-O-P]\left[P O O^{\circ}\right] \\
& \frac{d[N-O-P]}{d t}=k_{N 1}\left[N O^{\circ}\right]\left[P^{\circ}\right]-k_{N 2}[N-O-P]\left[P O O^{\circ}\right]
\end{aligned}
$$

\section{Modified Equations for PDCPD + Chimassorb 2020}

$$
\begin{aligned}
& \frac{d[\mathrm{POOH}]}{d t}=-k_{1 u}[\mathrm{POOH}]-2 k_{1 b}[\mathrm{POOH}]^{2}+k_{3}\left[\mathrm{POO}^{\circ}\right][\mathrm{PH}] \\
& +k_{5}\left(1-\gamma_{5}\right)\left[\mathrm{P}^{\circ}\right]\left[\mathrm{POO}^{\circ}\right]+k_{N H}[\mathrm{NH}]\left[\mathrm{POO}^{\circ}\right] \\
& +k_{N 2}[N-O-P]\left[P O O^{\circ}\right] \\
& \frac{d\left[\mathrm{P}^{\circ}\right]}{d t}=2 k_{1 u}[\mathrm{POOH}]+k_{1 b}[\mathrm{POOH}]^{2}-k_{2}\left[\mathrm{P}^{\circ}\right]\left[\mathrm{O}_{2}\right]+k_{3}\left[\mathrm{POO}^{\circ}\right][\mathrm{PH}] \\
& -2 k_{4}\left[P^{\circ}\right]^{2}-k_{5}\left[P^{\circ}\right]\left[\mathrm{POO}^{\circ}\right]+k_{a 2}\left[\mathrm{POO}^{\circ}\right][\mathrm{C}=\mathrm{C}] \\
& -k_{N 1}\left[N O^{\circ}\right]\left[P^{\circ}\right] \\
& \frac{d\left[\mathrm{POO}^{\circ}\right]}{d t}=k_{1 b}[\mathrm{POOH}]^{2}+k_{2}\left[\mathrm{P}^{\circ}\right]\left[\mathrm{O}_{2}\right]-k_{3}\left[\mathrm{POO}^{\circ}\right][\mathrm{PH}] \\
& -k_{5}\left[P^{\circ}\right]\left[P O O^{\circ}\right]-2 k_{6}\left[P^{\circ} O^{\circ}\right]^{2}-k_{a 2}\left[P O O^{\circ}\right][C=C] \\
& -k_{N H}[N H]\left[P O O^{\circ}\right]-k_{N 2}[N-O-P]\left[P O O^{\circ}\right] \\
& \frac{d[C=C]}{d t}=-k_{a 1}\left[P^{\circ}\right][C=C]-k_{a 2}\left[P O O^{\circ}\right][C=C]+\left(1-\gamma_{4}\right) k_{4}\left[P^{\circ}\right]^{2} \\
& +\left(1-\gamma_{5}\right) k_{5}\left[P^{\circ}\right]\left[P O O^{\circ}\right]+k_{N 2}[N-O-P]\left[P O O^{\circ}\right]
\end{aligned}
$$

Then, a series of equations describing the changes of Chimassorb 2020 will be added:

$$
\begin{aligned}
& \frac{d\left[N O O^{\circ}\right]}{d t}=k_{N}\left[N^{\circ}\right]\left[O_{2}\right]-2 k_{N O O}\left[N O O^{\circ}\right]^{2} \\
& \frac{d\left[N O^{\circ}\right]}{d t}=k_{N O O}\left[N O O^{\circ}\right]^{2}-k_{N 1}\left[N O^{\circ}\right]\left[P^{\circ}\right]+k_{N 2}[N-O-P]\left[P O O^{\circ}\right] \\
& \frac{d[N H]}{d t}=-k_{O 2}[N H]\left[O_{2}\right]-k_{N H}[N H]\left[P O O^{\circ}\right] \\
& \frac{d[N-O-P]}{d t}=k_{N 1}\left[N O^{\circ}\right]\left[P^{\circ}\right]-k_{N 2}[N-O-P]\left[P O O^{\circ}\right]
\end{aligned}
$$

\section{APPENDIX 3}

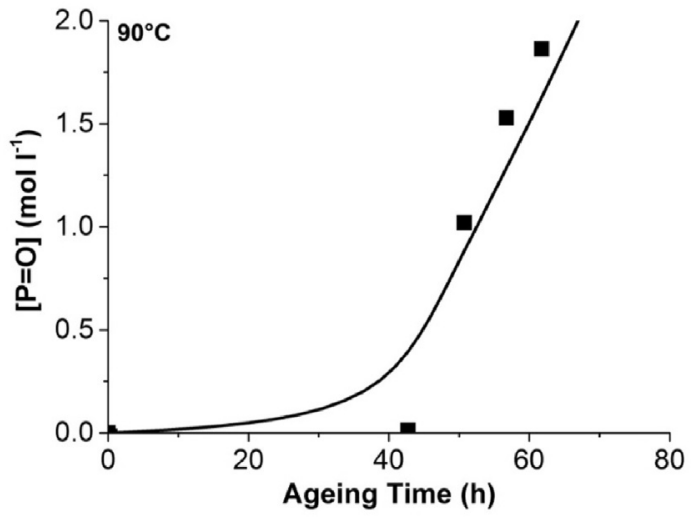

Fig. 9. Kinetic curves for carbonyl buildup and kinetic modeling for PDCPD + TEMPO $\left(10^{-2} \mathrm{~mol} \mathrm{l}^{-1}\right)$ at $90{ }^{\circ} \mathrm{C}$ with $\mathrm{k}_{\mathrm{N} 5}=10^{9}$ and $\mathrm{k}_{\mathrm{N} 6}=9000 \mathrm{l} \mathrm{mol}^{-1} \mathrm{~s}^{-1}$.

\section{References}

[1] J. Pospíšil, Mechanistic action of phenolic antioxidants in polymers-a review, Polym. Degrad. Stabil. 20 (1988) 181-202.

[2] P. Gijsman, A review on the mechanism of action and applicability of Hindered Amine Stabilizers, Polym. Degrad. Stabil. 145 (2017) 2-10.

[3] J. Malík, D.Q. Tuan, E. Śpirk, Lifetime prediction for HALS-stabilized LDPE and PP, Polym. Degrad. Stabil. 47 (1995) 1-8.

[4] N.C. Billingham, Designing polymer additives to minimise loss, Makromol. Chem., Macromol. Symp. 27 (1989) 187-205.

[5] H. Zweifel, S.E. Amos, Plastics Additives Handbook, Hanser Gardner Publications, 2001.

[6] J. Huang, W. Minne, R. Drozdzak, G. Recher, P.Y. Le Gac, E. Richaud, Thermal Oxidation of Poly(dicyclopentadiene) - Decomposition of Hydroperoxide Polym. Degrad. Stabil. 174 (2020) 109102.

[7] E. Richaud, P.Y. Le Gac, J. Verdu, Thermooxidative aging of polydicyclopentadiene in glassy state, Polym. Degrad. Stabil. 102 (2014) 95-104.

[8] V. Defauchy, P.Y. Le Gac, A. Guinault, J. Verdu, G. Recher, R. Drozdzak, E. Richaud, Kinetic analysis of polydicyclopentadiene oxidation, Polym. Degrad. Stabil. 142 (2017) 169-177.

[9] E. Oral, C. Godleski Beckos, A.S. Malhi, O.K. Muratoglu, The effects of high dose irradiation on the cross-linking of vitamin E-blended ultrahigh molecular weight polyethylene, Biomaterials 29 (26) (2008) 3557-3560.

10] P. Gijsman, W. Dong A. Quintana, M. Celina, Influence of temperature and stabilization on oxygen diffusion limited oxidation profiles of polyamide 6 Polym. Degrad. Stabil. 130 (2016) 83-96.

[11] https://polymer-additives.specialchem.com/product/a-basf-chimassorb-2020.

[12] J. Huang, A. David, P.-Y. Le Gac, C. Lorthioir, C. Coelho, E. Richaud, Therma oxidation of Poly(dicyclopentadiene)- kinetic modeling of double bond consumption, Polym. Degrad. Stabil. 166 (2019) 258-271.

13] E. Richaud, C. Monchy-Leroy, X. Colin, L. Audouin, J. Verdu, Kinetic modelling of stabilization coupled with stabilizer loss by evaporation. Case of dithioester stabilized polyethylene, Polym. Degrad. Stabil. 94 (2009) 2004-2014.

14] R. Gensler, C.J.G. Plummer, H.-H. Kausch, E. Kramer, J.-R. Pauquet, H. Zweifel, Thermo-oxidative degradation of isotactic polypropylene at high temperatures: phenolic antioxidants versus HAS, Polym. Degrad. Stabil. 67 (2000) 195-208.

[15] X. Gao, X. Meng, H. Wang, B. Wen, Y. Ding, S. Zhang, M. Yang, Antioxidan behaviour of a nanosilica-immobilized antioxidant in polypropylene, Polym. Degrad. Stabil. 93 (2008) 1467-1471.

16] B. Fayolle, L. Audouin, J. Verdu, A critical molar mass separating the ductile 
and brittle regimes as revealed by thermal oxidation in polypropylene, Polymer 45 (2004) 4323-4330.

[17] A. David, J. Huang, E. Richaud, P.Y. Le Gac. Impact of thermal oxidation on mechanical behaviour of pDCPD: case of non-diffusion limited oxidation. Submitted to Polymer Degradation and Stability.

[18] E. Richaud, B. Fayolle, J. Verdu, Polypropylene stabilization by hindered phenols - kinetic aspects, Polym. Degrad. Stabil. 96 (2011) 1-11.

[19] J. Pospíśil, J. Pilař, N.C. Billingham, A. Marek, Z. Horák S. Nešpůrek, Factors affecting accelerated testing of polymer photostability, Polym. Degrad. Stabil. 91 (2006) 417-422.

[20] C. Latocha, M. Uhniat, The kinetics of oxidative induction of LDPE stabilized with commercial antioxidants, Polym. Degrad. Stabil. 35 (1992) 17-22.

[21] N.C. Billingham, P.D. Calvert, I.W. Okopi, A. Uzuner, The solubility of stabilizing additives in polypropylene, Polym. Degrad. Stabil. 31 (1991) 23-36.

[22] N.C. Billingham, P.D. Calvert, A.S. Manke, Solubility of phenolic antioxidants in polyolefins, J. Appl. Polym. Sci. 26 (1981) 3543-3555.

[23] J. Malík, A. Hrivík, E. Tomová, Diffusion of hindered amine light stabilizers in low density polyethylene and isotactic polypropylene, Polym. Degrad. Stabil. 35 (1992) 61-66.

[24] E.B. Zeynalov, N.S. Allen, Modelling light stabilizers as thermal antioxidants, Polym. Degrad. Stabil. 91 (2006) 3390-3396.

[25] E. Richaud, X. Colin, C. Monchy-Leroy, L. Audouin, J. Verdu, Polyethylene stabilization against thermal oxidation by a trimethylquinoleine oligomer, Polym. Degrad. Stabil. 94 (2009) 410-420.

[26] E.B. Zeynalov, N.S. Allen, Modelling light stabilizers as thermal antioxidants, Polym. Degrad. Stabil. 91 (2006) 3390-3396.

[27] F. Gugumus, Advances in the stabilization of polyolefins, Polym. Degrad. Stabil. 24 (1989) 289-301.

[28] Y.G. Hsuan, R.M. Koerner, Antioxidant depletion lifetime in high density polyethylene geomembranes, Journal of Geotechnical and Geoenvironmental Engineering - ASCE 124 (1988) 532-541.

[29] I. Ahmad, C.Y. Li, Y.G. Hsuan, R.A. Cairncross, Reaction model describing antioxidant depletion in polyethylene-clay nanocomposites under therma aging, Polym. Degrad. Stabil. 110 (2014) 318-335.

[30] M. Coquillat, J. Verdu, X. Colin, L. Audouin, M. Celina, A kinetic evaluation of the thermal oxidation of a phenol stabilised polybutadiene, Polym. Degrad. Stabil. 93 (2008) 1689-1694.

[31] E. Richaud, Kinetic modelling of phenols consumption during polyethylene thermal oxidation, Eur. Polym. J. 49 (2013) 2232, 2223.

[32] J. Pospíšil, S. Nešpurek, H. Zweifel, The role of quinone methides in thermostabilization of hydrocarbon polymers-I. Formation and reactivity of quinone methides, Polym. Degrad. Stabil. 54 (1996) 7-14.

[33] E.T. Denisov, Mechanism of regeneration of hindered nitroxyl and aromatic amines, Polym. Degrad. Stabil. 25 (1989) 209-215.

[34] A. Faucitano, A. Buttafava, F. Martinotti, P. Bortolus, First electron spin resonance identification of a nitrogen peroxy radical as intermediate in the photooxidation of 2,2,6,6-tetramethylpiperidine derivatives, J. Phys. Chem. 88 (1984) 1187-1190.

[35] A. Faucitano, A. Buttafava, F. Martinotti, L. Greci, The mechanism of photostabilization by hindered amines: ESR evidence of dark reactions with regeneration of nitroxyl radicals in the inhibited photooxidation of polyolefin model systems, Polym. Degrad. Stabil. 35 (1992) 211-217.

[36] F. Gugumus, N. Lelli, Light stabilization of metallocene polyolefins, Polym. Degrad. Stabil. 72 (2001) 407-421.

[37] E.T. Denisov, I.B. Afanas'ev, Oxidation and Antioxidants in Organic Chemistry and Biology, CBC Taylor \& Francis Group, Boca Raton, London, New York, Singapore, 2005, p. 510.

[38] J. Chateauneuf, J. Lusztyk, K.U. Ingold, Absolute rate constants for the reactions of some carbon-centered radicals with 2,2,6,6-teramethylpiperidine-N-oxyl, J. Org. Chem. 53 (1988) 1629-1632.

[39] J. Nicolas, Y. Guillaneuf, C. Lefay, D. Bertin, D. Gigmes, B. Charleux review : nitroxide-mediated polymerization, Prog. Polym. Sci. 38 (2013) 63, 235.

[40] D.R. Bauer, J.L. Gerlock, Photo-stabilisation and photo-degradation of organic coatings containing a hindered amine light stabiliser: Part III-Kinetics of stabilisation during free radical oxidation, Polym. Degrad. Stabil. 14 (1986) 97-112.

[41] D.R. Bauer, J.L. Gerlock, D.F. Mielewski, Photo-degradation and photostabilization in organic coatings containing a hindered amine light stabilizer: Part VI-ESR measurements of nitroxide kinetics and mechanism of stabilization, Polym. Degrad. Stabil. 28 (1990) 115-129. 